\title{
FEATURE Managing the upper Missouri River for agriculture, irrigation, flood control, and energy
}

\author{
Kenneth R. Olson and Lois Wright Morton
}

$\mathrm{T}$ he Missouri River, the longest river in North America, has shaped the ancient and modern landscapes, cultures, and economies of Montana, North and South Dakota, Nebraska, western Iowa, Kansas, and Missouri. The agrarian heritage of the region is deeply rooted in the seeds planted in the Dakota soils and cultivated by the Mandan, Hidatsa, and Arikara Indians (Lewis and Clark Visitor Center 2016). The river flows $3,767 \mathrm{~km}$ (2,341 mi) east and south from the Rocky Mountains of western Montana through the shortgrass and tallgrass prairies of the Great Plains of the United States to its confluence with the Mississippi River at St. Louis, Missouri (figure 1).

Migrant and native peoples have depended on the Missouri River and its tributaries for transportation, food, and trade throughout North America for over 12,000 years or since the end of the Pleistocene period. The confluence with the Mississippi River links the entire Missouri River basin to the Gulf of Mexico and forms the third longest river system $(5,936 \mathrm{~km}[3,710 \mathrm{mi}])$ in the world. The lands adjacent to the broad, wide Missouri River are historically subject to flooding when the ice melts in the Rockies and heavy spring rains rush downstream making cities, agricultural lands, and their levees also vulnerable to flood pressures (Olson and Morton 2017). In late nineteenth and early twentieth centuries, a number of dams were built along the course of Missouri River, transforming 35\% of the river into a chain of lakes designed to manage downstream flood risks and provide hydroelectricity and agricultural irrigation. More recently, North Dakota has experienced an oil boom, and the region is crisscrossed with

Kenneth R. Olson is professor emeritus of soil science in the College of Agricultural, Consumer, and Environmental Sciences, University of Illinois, Urbana. Lois Wright Morton is professor emeritus of sociology in the College of Agriculture and Life Sciences, lowa State University, Ames, lowa.

\section{Figure 1}

The upper Missouri River basin has six main stem dams, which manage downstream flooding, provide hydroelectricity, and allow irrigation for agriculture. Map by Mic Greenberg.

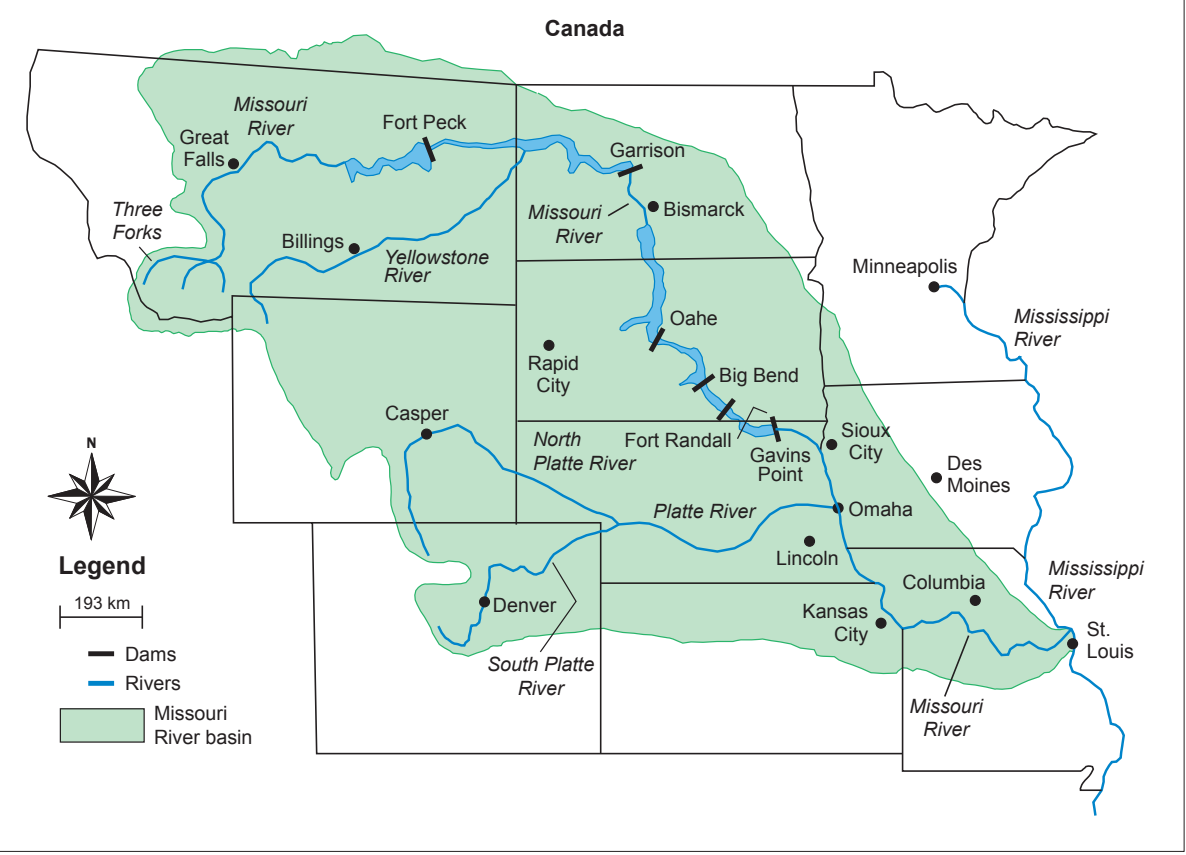

pipelines carrying oil and natural gas east and south to ports on the Gulf of Mexico.

The soil, water, and other natural resources of the upper Missouri River basin have never been more valued and critical to national security, and more vulnerable to degradation. Home to many different cultures and worldviews, the basin has regional, national, and global impacts, including boom-bust-boom industries and in- and out-migration of jobs; contested uses of the water, minerals, soils and other natural resources; and concerns about protection of the fragile soils, landforms, and views that draw visitors from around the world.

\section{ANCIENT MISSOURI RIVER VALLEY GEOLOGY}

At the end of Mesozoic and through early Cenozoic periods (70 to 45 million years ago), the Rocky Mountains of southwestern Montana rose during a mountain-building episode called the Laramide orogeny (Jones 2012). The
Cretaceous rocks in this orogeny formed a mountain range west of the Interior Seaway, a shallow sea that extended from the Arctic Ocean to the Gulf of Mexico. The Laramide uplift forced the sea to retreat and created the drainage systems of the modern day Missouri and Mississippi rivers. The sediments from this process are the parent materials and soils of the Missouri and Mississippi river basins (Olson and Morton 2017). The Laramide orogeny is the key to the Missouri River hydrology, with Rocky Mountain snow and ice melt the primary source of the Missouri River and tributary flows.

The Missouri River lies atop the Great Falls Tectonic Zone, an intracontinental shear zone between the Hearne and Wyoming provinces. The river forms near Three Forks, Montana, at the confluence of the Madison, Jefferson, and Gallatin rivers and drains $1,300,000 \mathrm{~km}^{2}\left(529,350 \mathrm{mi}^{2}\right)$ as it flows east and south. This semiarid watershed includes parts of 11 US states (figure 1) and two Canadian provinces, with the 
Missouri River valley ranging from $9.7 \mathrm{~km}$ (6 mi) to $16 \mathrm{~km}$ (10 mi) wide.

\section{LEWIS AND CLARK'S CORPS OF DISCOVERY TRIP}

The French and Spanish were the first Europeans in late seventeenth century to discover the unique Missouri River and its varied and rich resources. The land in the Missouri River basin was originally controlled by American Indians and then the Spanish and the French until it became part of the United States when President Thomas Jefferson agreed to the Louisiana Purchase. President Jefferson commissioned Meriwether Lewis and William Clark in 1803 to explore the Missouri River and find a water route to the Pacific Ocean (Ambrose 2005). It was known that the Columbia River system drained west out of the Rockies into the Pacific Ocean. The headwaters of the Missouri River had a similar latitude and, although maps of the region were scarce or nonexistent, it was widely thought that a short portage or connection between the two rivers existed.

In late 1803, Lewis and Clark received word that the United States had officially acquired New Orleans, Louisiana, and the Missouri River watershed or 2,144,510 $\mathrm{km}^{2}$ (828,000 $\mathrm{mi}^{2}$ ) (Olson and Morton 2017) mostly located in the Mississippi and Missouri river valleys from the French (figure 1). The Corps of Discovery led by Lewis and Clark left St. Louis, Missouri, in early summer of 1804 and by October passed the Grand River confluence with the Missouri River where the Arikaras Indians resided. The Arikaras were farmers and often traded with the Sioux to the south who brought trade goods in exchange for Arikaras grain crops grown mostly on the alluvial soils of the river bottomlands (Ambrose 2005). Upriver at a bend in the Missouri River in present-day North Dakota, the Corps built a winter camp near Mandan villages next to the Missouri River. At Mandan, they met a French Canadian, Toussaint Charbonneau, with his 16-year-old wife, Sacagawea, who was captured from the Shoshone Tribe that occupied land near the headwaters of the Missouri River at Three Forks, Montana. They served as interpreters and transla-

\section{Figure 2}

Meriwether Lewis on the trip up the Missouri River described in his notes a wide variety of animals including the majestic elk like this one in Yellowstone Park.

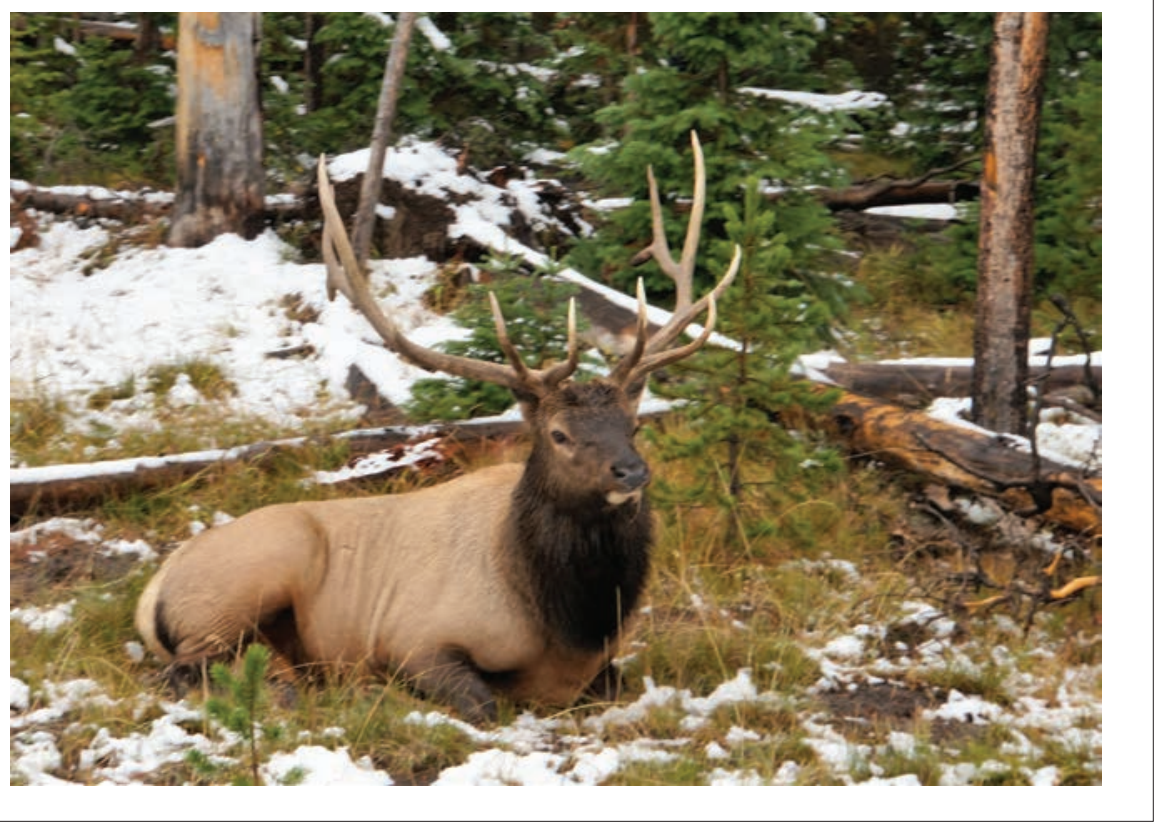

tors and were invaluable in guiding the Corps to the Missouri River headwaters. In spring and summer of 1805, the Corps continued their trip up the Missouri River with Lewis recording in his notes a diversity of plants and animals, such as elk (figure 2), pronghorn, and buffalo.

The Corps of Discovery expedition reached Three Forks of the Missouri on July $25,1805-4,000 \mathrm{~km}(2,500 \mathrm{mi})$ from their Woods River campsite near St. Louis. This presented a new dilemma: they needed to pick the correct fork. If they choose the wrong fork and had to backtrack, they would have had to spend the winter in the Rocky Mountains. At the Shoshone campgrounds, where Sacagawea had been captured five years before, Sacagawea reunited with her family, and the Shoshone warriors told Lewis and Clark the location of the Nez Perce trail with the Lemhi Pass that crossed the continental divide. This information enabled the Corps to cross the Rockies to the Snake River, a tributary of the Columbia River.

\section{DAM BUILDING ERA}

The Falls of the Missouri River (Great Falls, Montana) were one of the most aweinspiring phenomena of the Corps trip (figure 3) and a major obstacle to continu- ing upriver travel. A $16 \mathrm{~km}(10 \mathrm{mi})$ section of the river had five separate cascades with a combined height of $57 \mathrm{~m}$ (187 ft) with the river in-between the falls descending an additional $130 \mathrm{~m}$ (425 ft) for a total of a 187 $\mathrm{m}(612 \mathrm{ft})$ elevation drop. It took Lewis and Clark one month to portage $40 \mathrm{~km}$ (25 mi) around the Great Falls of Missouri.

Much like the falls in Minneapolis, Minnesota, on the upper Mississippi River (Olson and Morton 2016), the Great Falls of Missouri were a natural power source for the saw and flour mills and hydroelectricity that fueled the economic and social growth of Montana. Dams were built on the falls beginning in the 1880 s, and all but one of the falls, Crooked Falls, have been significantly altered or submerged. Black Eagle Dam (1890), the first hydroelectric dam in Montana, submerged half of Black Eagle Falls in the reservoir behind the dam (Federal Works Agency 1939). Rainbow Dam, built in 1910, significantly altered Rainbow Falls (Sanders 2003; Hebgen 1914), and the reservoir behind that dam submerged Colter Falls. Ryan Dam, built in 1915, has a hydroelectric powerhouse that covered a large portion of the $27 \mathrm{~m}$ $(87 \mathrm{ft})$ high waterfall, the largest of the five Great Falls of Missouri (figure 3). 


\section{Figure 3}

Ryan Dam (Great Falls, Montana) is constructed in the Missouri River gorge where the largest of the Great Falls is located. This $19 \mathrm{~m}$ high dam has the capacity to store $6,200,000 \mathrm{~m}^{3}$ of water in the reservoir behind the dam and can produce $60 \mathrm{MW}$ of electricity.

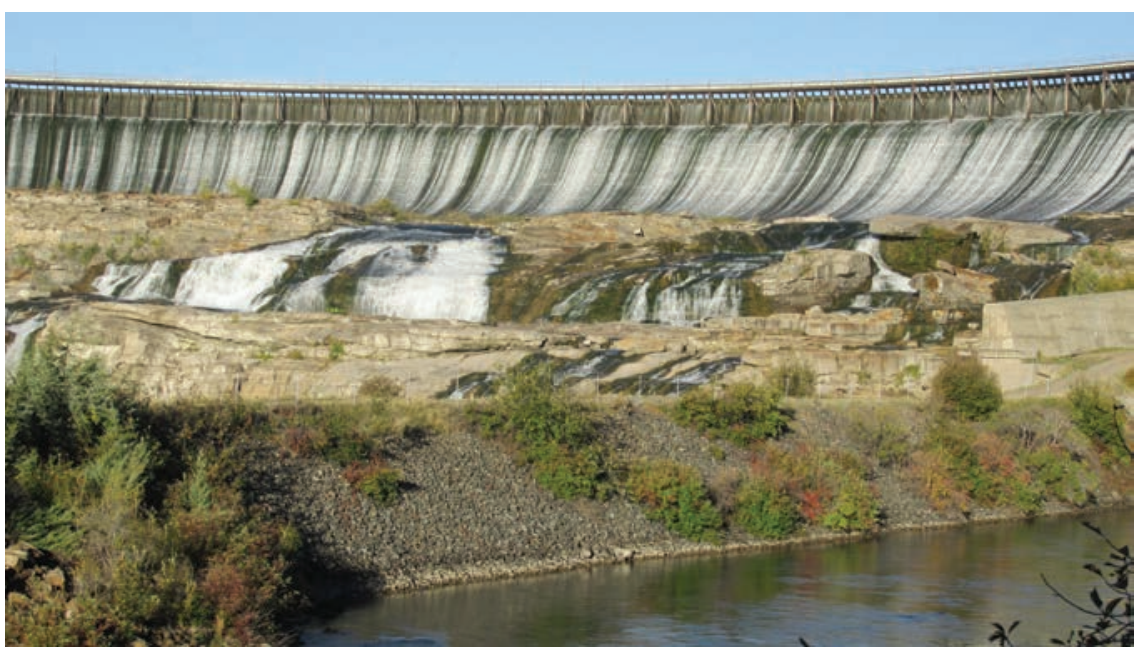

\section{Figure 4}

The Garrison Dam in North Dakota flooded the Missouri River valley upstream to form Sakakawea Lake.

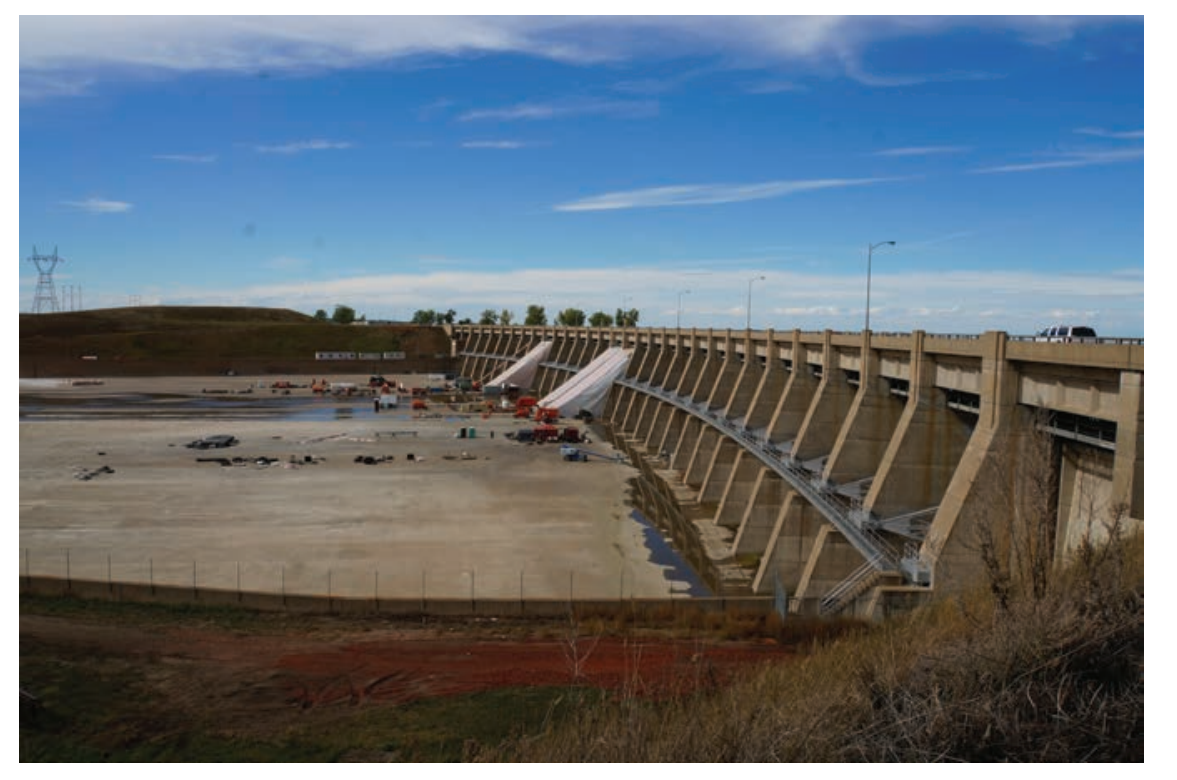

Dams were built for hydroelectric power and to control downstream flooding in the alluvial river plain. A series of catastrophic floods, with the worst in 1844, 1881, 1926 to 1927, 1993, and 2011 affected the Missouri Basin. In 1940, as part of the Great Depression era New Deal, the US Army Corps of Engineers (USACE) completed Fort Peck Dam in Montana (figure 1). The project provided jobs for 50,000 laborers and served to manage flooding in the lower half of the Missouri River basin. However, it controlled only $11 \%$ of the Missouri River watershed and was ineffective during the snowmelt flood that struck the basin in 1943, which submerged manufacturing plants in Omaha, Nebraska, and Kansas City, delaying military supply shipments during World War II.
The flood damages on the Mississippi and Missouri rivers were one of the reasons Congress passed the 1944 Act, which authorized the Pick-Sloan Missouri Basin Program to control flooding, develop hydroelectric power, and increase agricultural irrigation. Five more large dams were built along the main stem of the Missouri River, and approximately 85 smaller dams were added on tributaries.

In the 1950s, construction started on the five main stem dams: Garrison (figure 4), Oahe, Big Bend, Fort Randall, and Gavins Point (figure 1). These five dams and the 1940s Fort Peck Dam are among the largest dams in the world by volume and hold up to $91.4 \mathrm{~km}^{3}$ (74.1 million $\mathrm{ac}-\mathrm{ft}$ ). In addition to storing irrigation water, these dams have an annual floodcontrol reserve of $20.1 \mathrm{~km}^{3}$ (16.3 million $\mathrm{ac}-\mathrm{ft})$. Power plants on the main stem river generate about 33.5 billion MJ (9.3 billion $\mathrm{kWh}$ ) annually-equal to a constant output of almost 1,100 $\mathrm{MJ} \mathrm{s}^{-1}$ (1,100 MW). In conjunction with 100 smaller tributary dams primarily on the Bighorn, Platte, Kansas, and Osage rivers, the system supplies irrigation water to almost 19,000 $\mathrm{km}^{2}$ (7,500 $\mathrm{mi}^{2}$ ) of land (Johnston 2006).

Originally, a lower dam on the Missouri River at Riverdale, North Dakota, and 19 smaller dams on the Yellowstone River and its tributaries were proposed. The proposed dams on Yellowstone became quite controversial and were not constructed. The Garrison Dam at Riverdale was built higher to replace the water storage that Yellowstone dams would have provided, and the Yellowstone River remained free flowing.

\section{MISSOURI RIVER FLOOD OF 2011}

Dams reduced flooding along the Missouri River and its tributaries. However, in 2011, the convergence of record snowfall in the Montana and Wyoming Rocky Mountains and near record spring rainfall in central and eastern Montana put the Missouri River dams at capacity. The National Weather Service reported the 2011 total May precipitation as equivalent to almost a year's worth of rain over the upper Missouri River basin. The system was not able to handle the floodwaters, and several towns and cities as well as agricultural lands along the Missouri 
River from Montana to St. Louis, Missouri, were at risk or flooded when levees breached. All six major dams on the main stem Missouri were forced to release record amounts of water to prevent uncontrolled overflow or dam failure. The Missouri River flooding lasted from June through August of 2011 and led the USACE to release water throughout the $1,370 \mathrm{~km}$ (850 mi) river from Garrison Dam in North Dakota (figure 4) to the confluence with the Mississippi River north of St. Louis. The Garrison Dam began releasing a record $4,300 \mathrm{~m}^{3} \mathrm{~s}^{-1}$ $\left(152,000 \mathrm{ft}^{3} \mathrm{sec}^{-1}\right)$ to the Missouri River on June 1, 2011 (a month after the peak flooding on the Mississippi and Ohio rivers). Increasingly variable and extreme rain events in this region are projected to continue and are expected to increase upland runoff rates and river water volume and velocity, requiring the USACE to re-evaluate how they manage these reservoirs.

\section{HUMAN IMPACTS OF GARRISON DAM}

While the dams on the Missouri River provide hydroelectricity and flood management, the construction of dams and reservoirs flooded millions of hectares (millions of acres) of bottomland. The federal acquisition of land in the Missouri Valley uprooted and displaced thousands of people. Only the Yellowstone River valley was spared since local opposition prevented the proposed dams from being built. Congress authorized the Garrison Dam and Reservoir project in 1944. The dam design was raised an additional $10 \mathrm{~m}$ (33 ft) and flooded a large portion of alluvial lands primarily used for agriculture in North Dakota to form the $160 \mathrm{~km}(100$ mi) Sakakawea Lake. Farmers, landowners, homeowners, renters, and businesses lost homes and places of work when the towns of Sanish, Elbowoods, Lucky Mound, Shell Creek, Nishii, Charging Eagle, Beaver Creek, Red Butte, Independence, and Van Hook were covered by the reservoir. One town, called New Town, where people were relocated, was platted in 1950 north of Sakakawea Lake as a replacement for Sanish and Van Hook.

Little has been written about the displaced North Dakota, Montana, and Nebraska families and the human impacts associated with the construction of these 1940s and 1950s dams and reservoirs. The lead author's family - the Olson familywas one whose agricultural lands were lost by the damming of the Missouri River for flood control and hydroelectricity. The federal government purchased land and small towns and created the Garrison Dam and lake using the threat of eminent domain. This affected residents of Sanish and Van Hook. Many of the farmers and landowners (including the author's uncle, aunt, and their family) took the payment for their land and moved to New Town. They had to rent land to farm since very little land was available for purchase in the area surrounding the reservoir. Other farmers took their families and moved out of the area and state. At five years old, the author moved to Pennsylvania in 1952 with his parents and sister. There the family continued farming after purchasing a dairy farm in 1955 on the Pennsylvania uplands to avoid bottomlands that could be taken again for another dam and reservoir.

\section{THE YELLOWSTONE RIVER VALLEY}

The Yellowstone River, at $1,114 \mathrm{~km}$ (692 mi) long, is a major tributary of the Missouri River. It originates in the northern sections of Yellowstone Park and then runs north and exits the park at Gardiner, Montana. The Yellowstone then flows up ParadiseValley, a section of the river famous for trout fishing, to Livingston where the river turns northeast and converges with the Missouri River near the North Dakota border. The Yellowstone River is $25 \mathrm{~m}$ (75 $\mathrm{ft})$ to $90 \mathrm{~m}(300 \mathrm{ft})$ wide and encompasses $181,299 \mathrm{~km}^{2}\left(70,000 \mathrm{mi}^{2}\right)$. Although it has an average flow of $390 \mathrm{~m}^{3} \mathrm{~s}^{-1}\left(13,773 \mathrm{ft}^{3}\right.$ $\left.\mathrm{sec}^{-1}\right)$, it has extremes as low as $88 \mathrm{~m}^{3} \mathrm{~s}^{-1}$ $\left(3,108 \mathrm{ft}^{3} \mathrm{sec}^{-1}\right)$ and as high as 4,502 $\mathrm{m}^{3} \mathrm{~s}^{-1}$ $\left(159,000 \mathrm{ft}^{3} \mathrm{sec}^{-1}\right)$.

The Yellowstone River bottomlands and some terraces in Montana have been extensively irrigated for crops and animal agriculture since the 1860 s. Irrigation water comes from both the river and groundwater. Most of the bottomlands are irrigated from the river, and the terraces are irrigated from groundwater from wells with gravity flow ditches to the cropland. Dryland agriculture-wheat (Triticum aestivum L.) and grazing lands-occurs on terraces and upland foot slopes. Water is scarce in this dry region, and the division of water rights among Wyoming, Montana, and North Dakota is governed by a 1950 compact. A 2010 lawsuit between Montana and Wyoming disputed the terms. However, the suit was settled on May 2, 2011, when Montana's claim to additional water was declared invalid since Wyoming was irrigating the same acreage as always.

\section{AGRICULTURE IN THE MISSOURI RIVER VALLEY}

Changing climate patterns in this semiarid region and human engineered water management and redistribution have shifted land uses in the Missouri River valley. Alluvial river valleys that were dammed and flooded by reservoirs lost fertile agricultural area but irrigation made possible expanded agricultural uses in other sections of the river valley and dry uplands. An increasingly warming climate has moved the mesic-frigid soil temperature boundary northward in Montana, North Dakota, and South Dakota, extending the growing season and increasing winter and spring precipitation (Morton 2014). However, the region continues to be vulnerable to periodic drought and increased soil erosion and nutrient runoff with increased severity of heavy rainfall events and precipitation in the cool months (Shafer et al. 2014).

These factors have influenced reduction in total hectares (acres) in agriculture but expanded row crop hectares in the Dakotas from 1954 to 2012. The US Census of Agriculture (USDA 2012) shows over this 58 year period a loss of 1,000,000 ha $(2,500,000 \mathrm{ac})$ of agricultural land in North Dakota from 1954 (16,946,990 ha $[41,876,924 \mathrm{ac}])$ to $2012(15,889,000 \mathrm{ha}$ $[39,262,600 \mathrm{ac}])$. It appears that the two large reservoirs in North Dakota may have contributed to this loss of agricultural land. Irrigated cropland in 1964 was 34,398 ha $(85,000 \mathrm{ac})$ and increased to 845,570 ha $(2,089,451$ ac) by 2012 . Most of the increase in North Dakota irrigated cropland was from three crops: corn (Zea mays L.) for grain (from 944 to 36,984 ha [2,333 to $91,390 \mathrm{ac}]$ ), soybean (Glycine $\max$; from 291 ha $[720 \mathrm{ac}]$ to 12,418 ha $[30,688 \mathrm{ac}]$ ), and wheat (from 4,646 ha $[11,481 \mathrm{ac}]$ to $7,073 \mathrm{ha}[17,479 \mathrm{ac}])$. 
Overall, North Dakota total grain corn, wheat, and soybean area increased over the 58 year period: wheat land increased from $2,592,058$ ha $(6,405,115 \mathrm{ac})$ to $3,143,389$ ha $(7,767,484 \mathrm{ac})$, corn for grain increased from 159,567 ha $(394,300 \mathrm{ac})$ to $1,402,639$ ha $(3,465,997 \mathrm{ac})$, and soybean increased from 19,818 ha $(48,972 \mathrm{ac})$ to $1,913,813$ ha $(4,729,137 \mathrm{ac})$. There was an increase in sunflower (Helianthus annuus L.) crops from 813 ha $(2,010 \mathrm{ac})$ to 343,689 ha $(849,274 \mathrm{ac})$ and alfalfa (Medicago sativa L.) from 437,171 ha $(1,080,274 \mathrm{ac})$ to 491,023 ha $(1,213,345 \mathrm{ac})$. However, there was a decline in total hay lands from $1,438,624$ ha $(3,554,918 \mathrm{ac})$ in 1964 to 871,444 ha $(2,153,385 \mathrm{ac})$ in 2012.

South Dakota had 17,500,000 ha $(43,300,000 \mathrm{ac})$ total agricultural lands in 2012 , a decrease of 690,000 ha $(1,700,000$ ac) since 1954. There has been little change over time in wheat hectares (acres) and a 970,000 ha $(2,400,000 \mathrm{ac})$ decrease in total hay hectares. The three main stem reservoirs covered hundreds of thousands of hectares (hundreds of thousands of acres) of alluvial soils on the river bottomlands with water. The influence of more but variable precipitation and an extended growing season is reflected in an increase of 970,000 ha $(1,900,000 \mathrm{ac})$ of total corn grain and a 1,820,000 ha $(4,500,000 \mathrm{ac})$ increase in soybean and loss of hay hectares. Total sunflower hectares have increased dramatically, from $98 \mathrm{ha}(243 \mathrm{ac})$ in 1954 to 251,000 ha $(619,981 \mathrm{ac})$ in 2012.

North Dakota cattle numbers in 1954 were 2,103,901 and dropped to $1,809,613$ by 2012. During this period, sheep and lamb numbers dropped substantially from 697,643 to 64,607 , bison increased to 3,446 from 0 , and honey production increased from $2,581,053 \mathrm{~kg}(5,169,241 \mathrm{lb})$ in 1974 to $13,242,000 \mathrm{~kg}(29,193,610 \mathrm{lb})$ in 2012. South Dakota increased cattle production slightly to $3,900,000$ head in 2012, and honey production remained steady at almost 1,300,000 kg (16,000,000 lb).

\section{ENERGY DEVELOPMENT ON THE UPPER MISSOURI RIVER VALLEY}

The hydroelectric dams were the first efforts to provide for the energy and water needs of a growing population. As energy demands and technologies for mining and processing minerals grew, energy resources of the region became major drivers of state economies. Coal, oil, and natural gas as well as windmill and solar resources from Montana and the Dakotas currently supply regional, national, and global energy markets. Discovery of gold in 1862 in Montana began the race to extract the region's mineral wealth. In 2012, Montana produced $33,290 \mathrm{t}(36,694 \mathrm{tn})$ of coal, 26,500 barrels of oil, and almost 18,972,000 $\mathrm{m}^{3}(67 \mathrm{mil}-$ lion $\mathrm{ft}^{3}$ ) of natural gas.

North Dakota similarly has a wealth of coal, oil, and natural gas. In recent years, North Dakota has eclipsed Montana's energy production by producing 243,000 barrels of oil and 4,877,350 $\mathrm{m}^{3}\left(172,242,000 \mathrm{ft}^{3}\right)$ of natural gas in 2012. While South Dakota has no significant production of coal, barrels of oil production increased from 247,000 in 1964 to $1,756,000$ in 2012 , natural gas increased from 0 to $427,000 \mathrm{~m}^{3}(15,085,000$ $\mathrm{ft}^{3}$ ), and ethanol from 0 to $23,481,000$ barrels from 1964 to 2012.

\section{THE DAKOTA ACCESS (BAKKEN) PIPELINE}

The growth of the oil industry in North Dakota has brought challenges in transporting oil from this remote northern region southward to domestic refineries and US ports on the Gulf of Mexico. Kilometer (mile)-long trains have carried crude oil to the Gulf since 2008 and presented safety concerns for the highly volatile oil when train derailment and accidents at rail crossings occur. The solution, a 1,886 km (1,172 mi) long pipeline known as the Bakken or Dakota Access Pipeline (figure 5), has become a contentious cultural and environmental issue. The US $\$ 3.78$ billion dollar

\section{Figure 5}

The Dakota Access Pipeline begins in the Bakken oil fields of North Dakota and runs southeast across four states to a terminal at Patoka, Illinois. Map by Mic Greenberg.

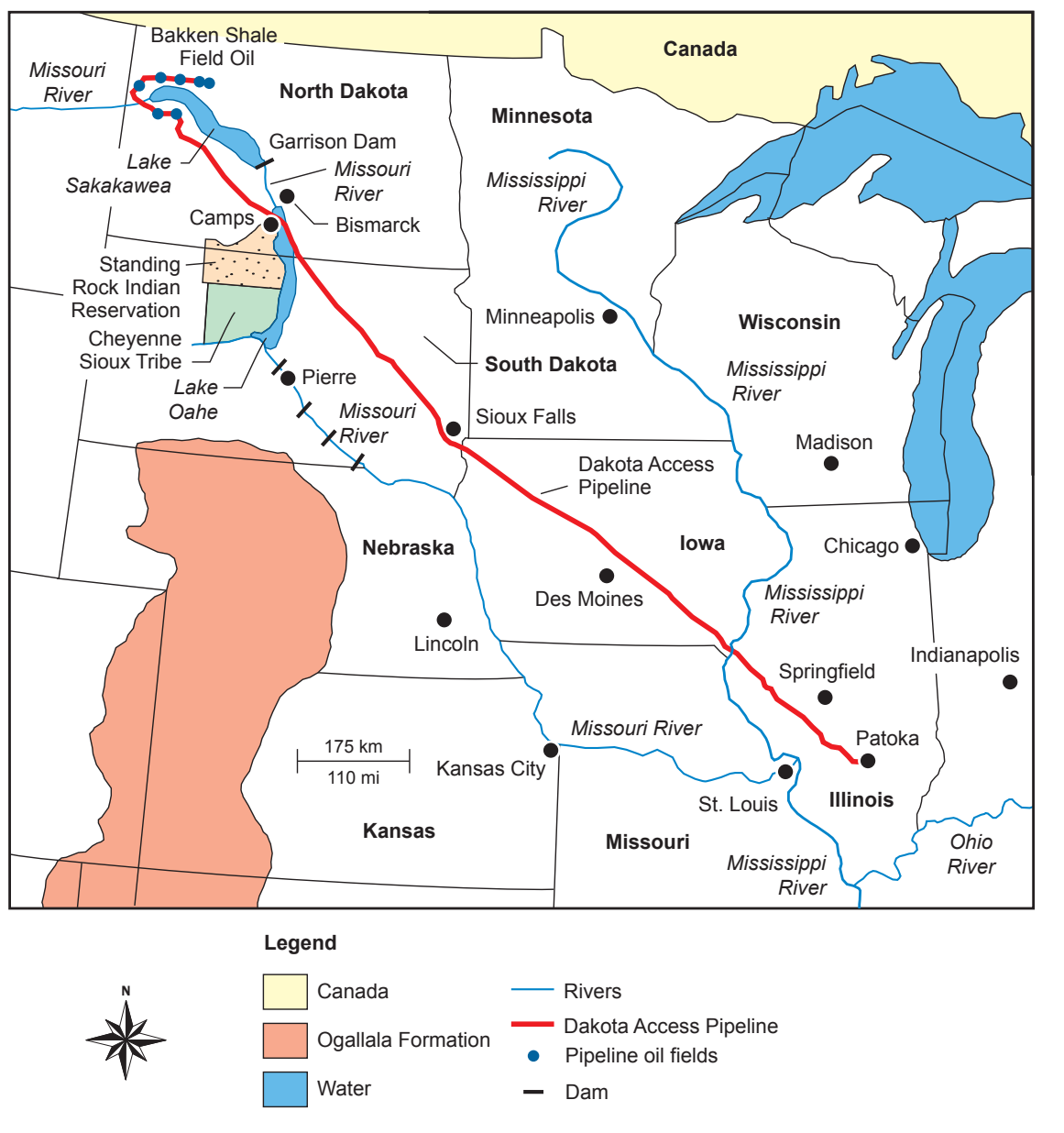


pipeline originates in the Bakken shale oil field of northwest North Dakota and runs southeast through South Dakota and Iowa, and terminates at Patoka, Illinois. It has a permanent easement of $15 \mathrm{~m}(50 \mathrm{ft})$ and construction right-of-way of $46 \mathrm{~m}(150 \mathrm{ft})$. The $7.6 \mathrm{~cm}$ (30 in) pipe was buried $1.2 \mathrm{~m}$ $(4 \mathrm{ft})$ underground or $0.6 \mathrm{~m}(2 \mathrm{ft})$ below farm drainage tile lines (Petroski 2014).

The original plan called for the first oil delivery on January 1, 2016, but public demonstrations and protests and lack of a USACE permit to bore under the Missouri River and Lake Oahe delayed the completion of the project. Environmentalists and American Indians have spoken out against the pipeline believing that spills could threaten their water supply, natural resources, and endangered species. Some farmers along the pipeline route have expressed concerns about the disturbance of land, tiling, soil erosion, soil quality, and potential of leaks in areas subject to flooding (Krause 2014).

The US State Department as part of Presidential Permit Review Process rejected the pipeline project when the Standing Rock Sioux Tribe filed a legal suit and protested in 2016. The protests stopped the construction of the 1,920 km (1,200 mi) oil pipeline and forced a reassessment of a long-standing treaty with American Indian tribes. During August and September of 2016, the protests accelerated when thousands of people from across the nation moved into two large camps near the Lake Oahe construction site and staged high profile demonstrations. A federal judge ruled that construction could continue but three federal agencies withheld a permit to cross under the Missouri River and Lake Oahe (figure 5). A federal appeals court on October 9, 2016, reaffirmed the lower court ruling and delayed the tribe's motion for a temporary injunction arguing the USACE did not adequately consult with tribes to protect their historical sites. Protests and lawsuits continued throughout 2016, and in early 2017, President Trump signed an executive order to restart the project. On June 2, 2017, the Dakota Access pipeline started shipping oil with projections of 470,000 barrels of oil transported daily (Stratton 2017).

\section{CONCLUSIONS}

The upper Missouri River basin has a rich agricultural tradition, extensive oil and mineral reserves, an abundant water supply, and scenic and recreational rivers and landscapes that draw people from around the world. President Thomas Jefferson was a man ahead of his time when he purchased most of the Missouri River watershed as part of the Louisiana Purchase. Thanks to President Jefferson's forward thinking and funding of the Corps of Discovery, the word of Lewis and Clark's successful adventure helped trigger US westward expansion during the 1810 s to 1860 s.

Future water management of the upper Missouri River and its tributaries faces many challenges and opportunities. Montana's long history of prior appropriation policies and protection of multiple uses and existing water rights have served the state well; however with population growth there are new pressures on water resources. The beauty of the Yellowstone and Missouri river landscapes and pristine waters offer recreational and economic opportunities that have made the state a tourist and retirement destination. The lack of rainfall initially restricted cultivation in the fertile soils of Montana, North Dakota, and South Dakota until irrigation was possible. The creation of six federal dams on the main stem of the Missouri River manages downstream flood control all the way to the confluence with the Mississippi River, provides hydroelectric power, and allows for local agricultural irrigation. These reservoir lakes cover extensive areas of productive alluvial soils on the river bottomlands. Water is the new "gold" of the region, scarce and valuable. Conflicts over water rights, water uses, threats to the environment from dams and flooding, and soil erosion and water degradation are likely to increase as this region grows and seeks to use the upper Missouri River to meet many competing needs and expectations. A public-private coordinated organization among the states much like the Mississippi River Commission is one strategy to more effectively plan, coordinate, and harmonize the management of this multifunctional river.

\section{REFERENCES}

Ambrose, A.E. 2005. Undaunted Courage. New York, NY: Simon and Schuster.

Federal Works Agency. 1939. Federal Writer's Project. Montana State guide book. Washington DC: Work Project Administration.
Hebgen, M. 1914. Hydroelectric Development in Montana. Bulletin No. 80, pp. 1910-1933.Transactions of the American Institute of Mining Engineers.

Illinois State Museum. 2011. The Mackay and Evans Map. Lewis and Clark in the Illinois Country. Springfield, IL: Illinois State Museum. http://www.museum.state.il.us/exhibits/ lewis_clark_il/htmls/il_country_exp/preps/ mackay_evans_map.html.

Johnston, P. 2006. History of the Pick-Sloan Program. World Environmental and Water Resources Congress. Reston, VA: American Society of Civil Engineers.

Jones, C.H. 2012. Photo map of the western United States: Cenozoic. Western US Tectonics. Boulder, CO: University of Colorado.

Krause, R. 2014. Hundreds pack inside Sioux Center meeting on proposed Dakota Access Pipeline Project. http://www.siouxlandproud.com/ news/local-news/hundreds-pack-inside-siouxcenter-meeting-on-propo/163614686.

Lewis and Clark Visitors Center. 2016 Exhibits. Mandan, North Dakota.

Morton, L.W. 2014. The science of variable climate and agroecosystem management. Journal of Soil and Water Conservation 69(6):207A-212A, doi:10.2489/jswc.69.6.207A.

Olson, K.R., and L.W. Morton. 2016. Managing Mississippi and Ohio River Landscapes. Ankeny, IA: Soil and Water Conservation Society.

Olson K.R., and L.W. Morton. 2017. Sedimentation, navigation, and agriculture on the lower Missouri River. Journal of Soil and Water Conservation 72(4):80A-86A, doi:10.2489/jswc.72.4.80A.

Petroski, W. 2014. Should farmers make way for the Bakken pipeline? Des Moines Register. August 25, 2014. http://www.desmoinesregister.com/story/news/2014/08/22/ farmers-make-way-bakken-pipeline/14426829/.

Sanders, R.A. 2003. Exploration into the World of Lewis and Clark. Vol. 3. Scituate, MA: Digital Scanning Inc.

Shafer, M., D. Ojima, J.M. Antle, D. Kluck, R.A. McPherson, S. Petersen, B. Scanlon, and K. Sherman. 2014. Chapter 19: Great Plains. Climate Change Impacts in the United States: The Third National Climate Assessment, eds. J. M. Melillo, T.C. Richmond and G.W. Yohe, 441-461. Washington, DC: US Global Change Research Program.

Stratton, A. 2017. Contested pipeline starts shipping oil. Wall Street Journal. June 2, 2017. A2.

USDA.2012.Census ofAgriculture.Washington,DC:USDA. https://www.agcensus.usda.gov/Publications/2012/ Full_Report/Volume_1,_Chapter_1_State_Level/. 